\title{
Studi Kasus Asuhan Keperawatan Psikososial Pada Tn. H Dengan Masalah Kecemasan
}

\author{
Meiwan Pasrah Christian Hulu
}

\author{
meiwanchristian@gmail.com
}

\section{BAB 1 \\ PENDAHULUAN}

\section{$1.1 \quad$ Latar Belakang}

Stroke merupakan salah satu masalah kesehatan yang ada dilingkungan masyarakat dan masalah kesehatan yang mematikan nomor tiga setelah penyakit jantung dan kanker,stroke biasanya ditandai dengan kelumpuhan anggota gerak pada salah satu sisi anggota tubuh (Insan, 2020). Stroke merupakan gangguan saraf yang disebabkan oleh gangguan aliran darah dalam otak dan stroke merupakan salah satu penyakit yang tidak menular (Leniwa,prabawati,\& Susilo, 2019). Stroke merupakan penyakit yang disebabkan oleh gangguan peredaran darah otak yang dipengaruhi oleh beberapa faktor risiko baik yang tidak dapat diubah seperti usia dan jenis kelamin maupun yang dapat diubah seperti hipertensi, diabetes melitus, dyslipidemia, dan pekerjaan (Layli, 2016). Berdasarkan hasil Riskesdes tahun 2018 di Indonesia angka kejadian stroke 12,1 kasus atau sebenyak 2.120.362 penduduk oleh laki-laki berusia 75 tahun keatas. Beberapa kota dengan presentasi cukup besar mempunyai penyakit stroke diantaranya : kalimantan timur $(14,7 \%)$, Aceh (1,6\%), Sumetera utara $(1,3 \%)$.

Stroke menyebabkan gangguan motorik, gangguan komunikasi verbal, gangguan persepsi, kerusakan fungsi kognitif dan gangguan psikologis serta disfungsi kandung kemih. Stroke dapat menyisaakan kelumpuhan terutama pada bahu, pola jalan yang salah dan masih banyak kondisi yang perlu dievaluasii oleh perawat.orang yang telah mengalami serangan stroke lebih mudah terkena serangan ulang stroke dan dampaknya lebih parah dari 
serangan pertama dimana angka kematian dan kecacatan lebih tinggi, kondisi ini dapat akan muncul kecemasan (Amila, Sinaga,\& Sembiring, 2019).

Kecemasan adalah ketegangan, rasa tidak aman dan kekhawatiran yang timbul karena dirasakan terjadi sesuatu yang tidak menyenangkan tetapi sumbernya sebagian besar tidak diketahui dan berasal dari dalam (Wahyuni, 2018). Kecemasan merupakan respon tubuh terhadap peristiwa yang terjadi, dimana respons tubuh terhadap peristiwa yang terjadi, dimana respon tubuh tersebut lebih bersifat negatif sehingga menimbulkan ketidaknyamanan bagi klien (Zaini, 2019). Kecemasan merupakan respon takut yang tidak jelas penyebabnya dan tidak didukung oleh situasi yang ada. Kecemasan dapat dirasakan oleh setiap orang jika mengalami tekanan dan perasaan mendalam yang menyebabkan masalah psikiatrik dan dapat berkembang dalam jangka waktu lama. (Marbun, Pardede \& Perkasa, 2019).

Kecemasan pada penderita Stroke merupakan gangguan psikologis yang sering dialami pasien stroke fase akut yang disebabkan oleh gangguan serebral atau merupakan reaksi (Amila \& Sembiring, 2020). Terapi hipnotis lima jari merupakan proses kekuatan pikiran dengan mengarahkan tubuh untuk menyebukan diri memelihara kesehatan relekasasi melalui komunikasi dalam tubuh melibatkan indra visual, sentuhan, pedoman, penglihatan dan pendengaran (Pardede, Simanjuntak \& Waruwu, 2020). Kecemasan mampu mengakibatkan perubahan-perubahan fisiologis yang dapat menghalangi dilakukannya tindakan yang akan di berikan kepada seseorang. Terapi hipnotis lima jari memampukan pasien dalam mengontrol nyeri, stres fisiologis dan emosi (Pardede, Hulu, \& sirait, 2021). Berdasarkan uraian diatas maka penulis tertarik untuk mengambil kasus kecemasan pada Stroke dengan judul Asuhan Keperawatan Pada Tn. H Dengan Kecemasan Pada Penderita Stroke Di Bakti Luhur Kec. Medan Helvetia. Pertimbangan utama pengambilan kasus ini pada Tn. H karena pada kehidupan sehari-hari memiliki tekanan darah tinggi dan ekstramitas bawah pincang saat berjalan sehingga pada kondisi lebih cepat mengalami cemas yang akan memperburuk kondisi. 


\subsection{Tujuan Penulisan}

\section{Tujuan umum}

Untuk memberikan asuhan keperawatan pada Tn. H dengan masalah kecemas

\section{Tujuan khusus}

a. Mahasiswa mampu melakukan pengkajian pada Tn. $\mathrm{H}$ dengan masalah kecemasan

b. Mahasiswa mampu melaksanakan diagnosa pada Tn. $\mathrm{H}$ dengan masalah kecemasan

c. Mahasiswa mampu membuat intervensi pada Tn. $\mathrm{H}$ dengan masalah kecemasan

d. Mahasiswa mampu melakukan implementasi pada Tn.H dengan masalah kecemasan

e. Mahasiswa mampu membuat evaluasi pada Tn. H dengan masalah kecemasan 


\section{BAB 2}

\section{TINJAUAN TEORITIS}

\subsection{Konsep Kecemasan}

\subsubsection{Defenis kecemesan}

Kecemasan adalah perasaan ketakutan yang tidak memiliki penyebab yang jelas dan tidak didukung oleh situasi,kecemasan dapat dirasakan oleh setiap orang jika mengalami tekanan dan perasaan yang mendalam menyebabkan masalah kejiwaan dan berkembangan dalam jangka panjang (Pardede, Simanjuntak \& Manulu, 2020). Kecemasan merupakan suatu respon psikologis maupun fisiologis individu terhadap suatu keadaan yang tidak menyenangkan, atau reaksi atas situasi yang dianggap mengancam (Hulu \& Pardede, 2016). Kecemasan merupakan suatu keadaan perasaan gelisah, ketidaktentuan, ada rasa takut dari kenyataan atau persepsi ancaman sumber aktual yang tidak diketahui masalahnya (Pardede \& Simangunsong, 2020)

Kecemasan merupakan bagian dari kondisi hidup artinya kecemasan ada pada setiap orang. Kecemasan merupakan sumber memotivasi untuk berbuat kearah kemajuan dan kessuksesan hidup, apabila kecemasan itu dalam kondisi normal ia akan menganggu kestabilan diri dan keseimbangan hidup (Hayat,2017). Kecemasan suatu kondisi perasaan yang berkaitan dengan ketakutan disertai gejala fisik seperti jantung berdebar nafas pendek atau nyeri dada, keringat dingin tangan geetaran yang dapat disebabkan oleh genetik, biokimia otak dan mekanisme fight-fight.( Febrianti, Hamid, \& Wardani, 2015) Kecemasan adalah perasaan was-was, khawatir,atau tidak nyaman seakan-akan akan terjadi sesuatu yang dirasakan sebagai ancaman Ansietas berbeda dengan rasa takut. Takut merupakan penilaian intelektual terhadap ssuatu yang berbahaya, sedangkan ansietas adalah respon emosional terhadap penilaian tersebut (Nurhalimah, 2016).

Kecemasan merupakan suatu perasaan subjektif mengenai ketegangan mental yang menggelisahkan sebagai reaksi umum dari ketidak mampuan mengatasi suatu masalah atau tidak adanya rasa aman. 
Perasaan yang tidak menentu tersebut pada umumnya tidak menyenangkan yang nantinya akan menimbulkan atau disertai perubahan fisiologis dan psikologis (Lestari, 2018)

Kecemasan mungkin hadir pada beberapa tingkat dalam kehidupan setiap individu, tetapi derajat dan frekuensi dengan yang memanifestasikan berbeda secara luas. Respon masing-masing individu memiliki kecemasan berbeda. Tepi emosional yang memprovokasi kecemasan untuk merangsang kreativitas atau kemampuan pemecahan masalah, yang lainnya dapat menjadi bergerak ke tingkat patologis. Perasaan umumnya dikategorikan menjadi empat tingkat untuk tujuan pengobatan : ringan, sedang, berat, dan panik. Perawat dapat menemukan klien cemas di mana saja di rumah sakit atau lingkup masyarakat.

Strategi coping sebagai bentuk usaha kognitif dan perilaku yang dilakukan untuk mengatur tuntutan internal dan eksternal yang timbul dari hubungan individu dengan lingkungan, yang dianggap menganggu batas-batas yang dimiliki oleh individu Terdapat dua jenis strategi koping yang biasanya digunakan oleh individu. Fokus kopingpada emosi (emotion focus coping) adalah mengarahkan respon kontrol emosi pada situasi yang penuh stres (Pardede, Keliat, Damanik \& Gulo, 2020).

\subsubsection{Etiologi Kecemasan}

\section{Faktor predisposisi}

Stressor predisposisi adalah semua ketegangan dalam kehidupan yang dapat menyebabkan timbulnya kecemasan (Stuart, Keliat \& Pasaribu, 2016). Ketegangan dalam kehidupan tersebut dapat berupa

a. Peristiwa Traumatik, yang dapat memicu terjadinya kecemasan berkaitan dengan krisis yang dialami individu baik krisis perkembangan atau situasional. 
b. Konflik Emosional, yang dialami individu dan tidak terselesaikan dengan baik. Konflik antara id dan superego atau antara keinginan dan kenyataan dapat menimbulkan kecemasan pada individu.

c. Konsep diri terganggu akan menimbulkan ketidakmampuan individu berpikir secara realitas sehingga akan menimbulkan kecemasan.

d. Frustasi akan menimbulkan rasa ketidakberdayaan untuk mengambil keputusan yang berdampak terhadap ego.

e. Gangguan fisik akan menimbulkan kecemasan karena merupakan ancaman terhadap integritas fisik yang dapat mempengaruhi konsep diri individu.

f. Pola mekanisme koping keluarga atau pola keluarga menangani stress akan mempengaruhi individu dalam berespon terhadap konflik yang dialami karena pola mekanisme koping individu banyak dipelajari dalam keluarga.

g. Riwayat gangguan kecemasan dalam keluarga akan mempengaruhi respons individu dalam berespons terhadap konflik dan mengatasi kecemasannya.

h. Medikasi yang dapat memicu terjadinya kecemasan adalah pengobatan yang mengandung benzodiazepin, karena benzodiazepine dapat menekan neurotransmiter gamma amino butyric acid (GABA) yang mengontrol aktivitas neuron di otak yang bertanggung jawab menghasilkan kecemasan.

\section{Faktor presipitasi}

Stresor presipitasi adalah semua ketegangan dalam kehidupan yang dapat mencetuskan timbulnya kecemasan (Stuart, Keliat \& Pasaribu, 2016). Stressor presipitasi kecemasan dikelompokkan menjadi dua bagian, yaitu :

a. Ancaman terhadap integritas fisik. Ketegangan yang mengancam integritas fisik yang meliputi : 
1) Sumber Internal, meliputi kegagalan mekanisme fisiologis sistem imun, regulasi suhu tubuh, perubahan biologis normal (misalnya : hamil).

2) Sumber Eksternal, meliputi paparan terhadap infeksi virus dan bakteri, polutan lingkungan, kecelakaan, kekurangan nutrisi, tidak adekuatnya tempat tinggal.

b. Ancaman terhadap harga diri meliputi sumber internal dan eksternal :

1) Sumber Internal : kesulitan dalam berhubungan interpersonal di rumah dan tempat kerja, penyesuaian terhadap peran baru. Berbagai ancaman terhadap integritas fisik juga dapat mengancam harga diri.

Sumber Eksternal : kehilangan orang yang dicintai, perceraian, perubahan status pekerjaan, tekanan kelompok, sosial budaya.

\subsubsection{Rentang respon}

Menurut Stuart (2006) "menjelaskan rentang respon individu terhadap cemas berfluktuasi antara respon adaptif dan maladaptif. Rentang respon yang paling adaptif adalah antisipasi dimana individu siap siaga untuk beradaptasi dengan cemas yang mungkin muncul. Sedangkan rentang yang paling maladaptif adalah panik dimana individu sudah tidak mampu lagi berespon terhadap cemas yang dihadapi sehingga mengalami ganguan fisik, perilaku maupun kognitif. Seseorang berespon adaptif terhadap kecemasannya maka tingkat kecemasan yang dialaminya ringan, semakin maladaptif respon seseorang terhadap kecemasan maka semakin berat pula tingkat kecemasan yang dialaminya, seperti gambar dibawah ini :"

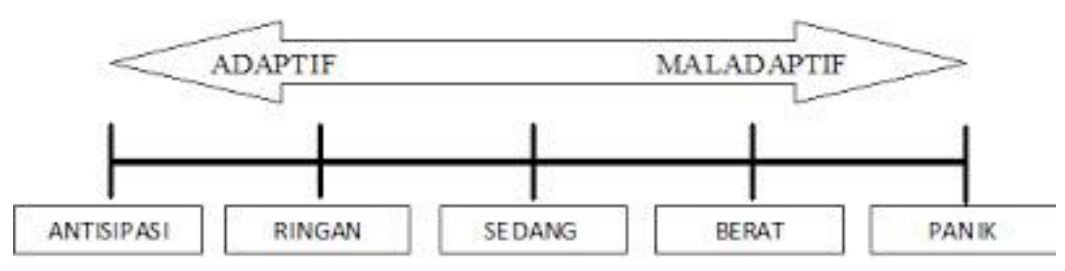




\subsubsection{Tanda dan Gejala Kecemasan}

Menurut Utami, Astuti\& Livana (2017) tanda dan gejala kecemasan adalah :

\section{Respons fisik :}

a. Kardiovaskular : Palpitasi, Jantung Bedebar, Tekanan Darah Meninggi, Denyut Nadi Cepat

b. Pernafasan : Napas Cepat, Napas Pendek, Tekanan Pada Dada, Napas Dangkal, Pembengkakan Pada Tenggorokan, TerengahEngah

c. Neuromuskular : Refleks Meningkat, Insomnia, Tremor, Gelisah, Wajah Tegang, Kelemahan Umum, Kaki Goyah, Gerakan Yang Janggal

d. Gastrointestinal : Anoreksia, Diare/Konstipasi, Mual, Rasa Tidak Nyaman Pada Abdomen

e. Traktur Urinarius : Sering Berkemih Dan Tidak Dapat Menahan Kencing

f. Kulit : Wajah Kemerahan, Berkeringat, Gatal, Rasa Panas Pada Kulit

\section{Respons Kognitif :}

Lapang persepsi menyempit, tidak mampu menerima rangsang luar, berfokus pada apa yang menjadi perhatiannya

\section{Respons Perilaku :}

Gerakan tersentak-sentak, bicara berlebihan dan cepat, perasaan tidak aman.

\section{Respons Emosi :}

Menyesal, iritabel, kesedihan mendalam, takut, gugup, sukacita berlebihan, ketidakberdayaan meningkat secara menetap, 
ketidakpastian, kekhawatiran meningkat, fokus pada diri sendiri, perasaan tidak adekuat, ketakutan, distressed, perihatin.

\subsubsection{Penatalaksanaan Kecemasan}

Menurut Hawari (2008) penatalaksanaan ansietas pada tahap pencegahaan dan terapi memerlukan suatu metode pendekatan yang bersifat holistik, yaitu mencangkup fisik (somatik), psikologik atau psikiatrik, psikososial dan psikoreligius. Selengkpanya seperti pada uraian berikut :

1. Upaya meningkatkan kekebalan terhadap stress, dengan cara :

a. Makan makanan yang berigizi dan seimbang

b. Tidur yang cukup

c. Olahraga yang teratur

d. Tidak merokok dan tidak minum minuman keras

\section{Terapi Psikofarmaka}

Terapi psikofarmaka yang sering dipakai adalah obat anti cemas (anxiolytic), yaitu seperti diazepam, clobazam, bromazepam, lorazepam, buspirone $\mathrm{HCl}$, meprobamate dan alprazolam.

3. Terapi Somatik

Gejala atau keluhan fisik (somatik) sering dijumpai sebagai gejala ikutan atau akibat dari kecemasan yang bekerpanjangan. Untuk menghilangkan keluhan-keluhan somatik (fisik) itu dapat diberikan obat-obatan yang ditujukan pada organ tubuh yang bersangkutan.

4. Psikoterapi

Psikoterapi diberikan tergantung dari kebutuhan individu, antara lain

a. Psikoterapi Suportif

b. Psikoterapi Re-Edukatif

c. Psikoterapi Re-Konstruktif

d. Psikoterapi Kognitif

e. Psikoterapi Psikodinamik

f. Psikoterapi Keluarga

5. Terapi Psikoreligius 
Untuk meningkatkan keimanan seseorang yang erat hubungannya dengan kekebalan dan daya tahan dalam menghadapi berbagai problem kehidupan yang merupakan stressor psikososial.

\subsection{Konsep Asuhan Keperawatan}

\subsubsection{Pengkajian}

\section{Faktor Predisposisi}

Berbagai teori telah dikembangkan untuk menjelaskan asal ansietas (Waryuningsih,2021) :

\section{a. Teori Psikoanalitik}

Ansietas adalah konflik emosional yang terjadi antara dua elemen kepribadian, ID dan superego. ID mewakili dorongan insting dan impuls primitif seseorang, sedangkan superego mencerminkan hati nurani seseorang dan dikendalikan oleh norma- norma budaya seseorang. Ego atau Aku, berfungsi menengahi hambatan dari dua elemen yang bertentangan dan fungsi ansietas adalah mengingatkan ego bahwa ada bahaya

\section{b. Teori Interpersonal}

Ansietas timbul dari perasaan takut terhadap tidak adanya penerimaan dari hubungan interpersonal. Ansietas juga berhubungan dengan perkembangan, trauma seperti perpisahan dan kehilangan sehingga menimbulkan kelemahan spesifik.Orang dengan harga diri rendah mudah mengalami perkembangan ansietas yang berat.

\section{c. Teori Perilaku}

Ansietas merupakan produk frustasi yaitu segala sesuatu yang mengganggu kemampuan seseorang untuk mencapai tujuan yang diinginkan.Daftar tentang pembelajaran meyakini bahwa individu yang terbiasa dalam kehidupan dininya dihadapkan pada ketakutan yng berlebihan lebih sering menunjukkan ansietas pada kehidupan selanjutnya.

\section{d. Kajian Keluarga}


Menunjukkan bahwa gangguan ansietas merupakan hal yang biasa ditemui dalam suatu keluarga.Ada tumpang tindih dalam gangguan ansietas dan antara gangguan ansietas dengan depresi.

\section{e. Kajian Biologis}

Menunjukkan bahwa otak mengandung reseptor khusus benzodiazepine. Reseptor ini mungkin membantu mengatur ansietas penghambat dalam aminobutirik. Gamma neuroregulator (GABA) juga mungkin memainkan peran utama dalam mekanisme biologis berhubungan dengan ansietas sebagaimana halnya endorfin. Selain itu telah dibuktikan kesehatan umum seseorang mempunyai akibat nyata sebagai predisposisi terhadap ansietas. Ansietas mungkin disertai dengan gangguan fisik dan selanjutnya menurunkan kapasitas seseorang untuk mengatasi stressor.

\section{Faktor Presipitasi}

Stressor pencetus mungkin berasal dari sumber internal atau eksternal. Stressor pencetus dapat dikelompokkan menjadi 2 kategori (Pratiwi, Widianti \& Solehati, 2017):

a. Ancaman terhadap integritas seseorang meliputi ketidakmampuan fisiologis yang akan datang atau menurunnya kapasitas untuk melakukan aktifitas hidup sehari- hari.

b. Ancaman terhadap sistem diri seseorang dapat membahayakan identitas, harga diri dan fungsi sosial yang terintegrasi seseorang.

\section{Perilaku}

Kecemasan dapat diekspresikan secara langsung melalui perubahan fisiologi dan perilaku dan secara tidak langsung melalui timbulnya gejala atau mekanisme koping dalam upaya melawan kecemasan. Intensitas perilaku akan meningkat sejalan dengan peningkatan tingkat kecemasan. 
a. Respon Fisiologis Terhadap Ansietas

\begin{tabular}{|c|c|}
\hline Sistem Tubuh & Respons \\
\hline Kardiovaskuler & $\begin{array}{l}\text { - Palpitasi. } \\
\text { - Jantung berdebar. } \\
\text { - Tekanan darah meningkat dan denyut nadi menurun. } \\
\text { - Rasa mau pingsan dan pada akhirnya pingsan. }\end{array}$ \\
\hline Pernafasan & $\begin{array}{l}\text { - } \quad \text { Napas cepat. } \\
\text { - } \quad \text { Pernapasan dangkal. } \\
\text { - } \quad \text { Rasa tertekan pada dada. } \\
\text { - } \quad \text { Pembengkakan pada tenggorokan. } \\
\text { - } \quad \text { Rasa tercekik. } \\
\text { - } \quad \text { Terengah-engah. }\end{array}$ \\
\hline Neuromuskular & $\begin{array}{l}\text { - } \text { Peningkatan reflek. } \\
\text { - } \text { Reaksi kejutan. } \\
\text { - } \text { Insomnia. } \\
\text { - Ketakutan. } \\
\text { - Gelisah. } \\
\text { - } \text { Wajah tegang. } \\
\text { - Kelemahan secara umum. } \\
\text { - Gerakan lambat. } \\
\text { - Gerakan yang janggal. }\end{array}$ \\
\hline Gastrointestinal & $\begin{array}{l}\text { - } \text { Kehilangan nafsu makan. } \\
\text { - } \text { Menolak makan. } \\
\text { - } \text { Perasaan dangkal. } \\
\text { - Rasa tidak nyaman pada abdominal. } \\
\text { - Rasa terbakar pada jantung. } \\
\text { - Nausea. } \\
\text { - } \text { Diare. }\end{array}$ \\
\hline
\end{tabular}




\begin{tabular}{|l|ll|}
\hline Perkemihan & $\bullet$ & Tidak dapat menahan kencing. \\
& - & Sering kencing. \\
\hline Kulit & - & Rasa terbakar pada mukosa. \\
& - & Berkeringat banyak pada telapak tangan. \\
& - Gatal-gatal. \\
& - Perasaan panas atau dingin pada kulit. \\
& - Muka pucat dan bekeringat diseluruh tubuh. \\
\hline
\end{tabular}

b. Respon Perilaku Kognitif

\begin{tabular}{|c|c|}
\hline Sistem & Respons \\
\hline Perilaku & $\begin{array}{l}\text { - } \text { Gelisah. } \\
\text { - } \text { Ketegangan fisik. } \\
\text { - } \text { Tremor. } \\
\text { - Gugup. } \\
\text { - } \text { Bicara cepat. } \\
\text { - } \text { Tidak ada koordinasi. } \\
\text { - Kecenderungan untuk celaka. } \\
\text { - } \text { Menarik diri. } \\
\text { - } \text { Menghindar. } \\
\text { - Terhambat melakukan aktifitas. }\end{array}$ \\
\hline Kognitif & $\begin{array}{l}\text { - } \text { Gangguan perhatian. } \\
\text { - Konsentrasi hilang. } \\
\text { - } \text { Pelupa. } \\
\text { - Salah tafsir. } \\
\text { - Adanya bloking pada pikiran. } \\
\text { - Menurunnya lahan persepsi. } \\
\text { - Kreatif dan produktif menurun. } \\
\text { - Bingung. }\end{array}$ \\
\hline
\end{tabular}




\begin{tabular}{|c|c|}
\hline & $\begin{array}{l}\text { - Khawatir yang berlebihan. } \\
\text { - } \quad \text { Hilang menilai objektifitas. } \\
\text { - } \quad \text { Takut akan kehilangan kendali. } \\
\text { - Takut yang berlebihan. }\end{array}$ \\
\hline Afektif & $\begin{array}{l}\text { - } \text { Mudah terganggu. } \\
\text { - } \text { Tidak sabar. } \\
\text { - } \text { Gelisah. } \\
\text { - } \text { Tegang. } \\
\text { - Nerveus. } \\
\text { - } \text { Ketakutan. } \\
\text { - } \text { Alarm. } \\
\text { - } \text { Tremor. } \\
\text { - Gugup. } \\
\text { - } \text { Gelisah. }\end{array}$ \\
\hline
\end{tabular}

\section{Sumber Koping}

Individu dapat mengalami stress dan ansietas dengan menggerakkan sumber koping tersebut di lingkungan. Sumber koping tersebut sebagai modal ekonomok, kemampuan penyelesaian masalah, dukungan sosial dan keyakinan budaya dapat membantu seseorang mengintegrasikan pengalaman yang menimbulkan stress dan mengadopsi strategi koping yang berhasil(Sulastri, Trilianto \& Ermaneti,2019).

\section{Mekanisme Koping}

Ketika mengalami ansietas individu menggunakan berbagai mekanisme koping untuk mencoba mengatasinya dan ketidakmampuan mengatasi ansietas secara konstruktif merupakan penyebab utama terjadinya perilaku patologis. Ansietas tingkat 
ringan sering ditanggulangi tanpa yang serius.Tingkat ansietas sedang dan berat menimbulkan 2 jenis mekanisme koping (Sumoked, Wowiling\& Rompas, 2019) :

a. Reaksi yang berorientasi pada tugas, yaitu upaya yang disadari dan berorientasi pada tindakan untuk memenuhi secara realitis tuntutan situasi stress.

b. Mekanisme pertahanan ego, membantu mengatasi ansietas ringan dan sedang, tetapi jika berlangsung pada tingkat sadar dan melibatkan penipuan diri dan distorsi realitas, maka mekanisme ini dapat merupakan respon maladaptif terhadap stress.

\subsubsection{Diagnosa Keperawatan}

Adapun diagnosa yang biasanya muncul adalah :

1. Koping Individu Tidak Efektif

2. Kecemasan

3. Ketidakberdayaan

4. Isolasi Sosial

5. Perubahan Proses Berfikir

\subsubsection{Intervensi Keperawatan}

\section{Kecemasan}

Tujuan :

- Klien mampu mengenal pengertian penyebab tanda gejala dan akibat

- Klien mampu mengetahui cara mengatasi ansietas

- Klien mampu mengatasi ansietas dengan melakukan latihan relaksasi tarik nafas dalam

- Klien mampu mengatasi ansietas dengan melakukan latihan distraksi

- Klien mampu mengatasi ansietas dengan melakukan hipnotis lima jari

- Klien mampu merasakan manfaat dari latihan yang dilakukan 
- Klien mampu membedakan perasaan sebelum dan sesudah latihan

Tindakan :

a. Kaji tanda dan gejala ansietas dan kemampuan klien mengurangi kecemasan

b. Jelaskan tanda dan gejala, penyebab dan akibat dari kecemasan

c. Latihan cara mengatasi kecemasan :

1) Teknik relaksasi napas dalam

2) Distraksi : bercakap-cakap hal positif

3) Hipnotis 5 jari fokus padahal-hal yang positif

d. Bantu klien melakukan latihan sesuai dengan jadwal kegiatan.

\section{Koping tidak efektif}

Tujuan :

- Klien mampu mengetahui perubahan kondisi kesehatan dan kemampuannya mengatasi perubahan

- Klien mampu mengetahui pengertian tanda dan gejala penyebab serta akibat dari ketidakefektifan koping

- Klien mampu mengetahui cara mengatasi ketidakefektifan koping

- Klien mampu mengatasi masalah secara bertahap

- Klien mampu menggunakan sumber/daya sistem pendukung dalam mengatasi masalah

- Klien mampu merasakan manfaat latihan yang dilakukan

- Klien mampu mengembangkan koping yang efektif klien mampu merasakan manfaat sistem pendukung

Tindakan :

a. Kaji tanda dan gejala ketidakefektifan koping

b. Jelaskan proses terjadinya ketidakefektifan koping

c. Diskusikan koping (upaya atau cara) mengatasi masalah pada masa lalu 
d. Koping (upaya) yang berhasil dan tidak berhasil. Berikan pujian

e. Pemanfaatan sumber daya atau sistem pendukung dalam mengatasi masalah

f. Latihan menggunakan upaya menyelesaikan masalah saat ini dengan menggunakan cara lama yang berhasil atau cara baru.

- Buat daftar masalah yang dihadapi

- Buat daftar cara (lama dan baru) yang akan digunakan

- Pilih, latih, dan jadwalkan cara yang akan digunakan untuk masalah yang dihadapi

- Evaluasi hasil jika berhasil dibudidayakan jika kurang berhasil dipilih cara lain pada daftar cara nomor kedua

g. Latih menggunakan sistem pendukung yang teratur

h. Beri motivasi dan pujian atas keberhasilan klien mengatasi masalah

\section{Gangguan citra tubuh}

Tujuan :

- Klien mampu mengenal bagian tubuh yang sehat dan yang terganggu atau sakit

- Klien mampu mengetahui cara mengatasi gangguan citra tubuh

- Klien mampu mengafirmasi bagian tubuh yang sehat

- Klien mampu melatih dan menggunakan bagian tubuh yang sehat

- Klien mampu merawat dan melatih bagian tubuh yang terganggu

- Klien mampu mengevaluasi manfaat yang telah dirasakan dari bagian tubuh yang terganggu

- Klien mampu mengevaluasi manfaat bagian tubuh yang masih sehat

- Klien mampu merasakan manfaat latihan pada bagian tubuh yang terganggu

Tindakan :

a. Kaji tanda dan gejala gangguan citra tubuh dan kemampuan klien mengatasinya. 
b. Jelaskan tanda dan gejala, penyebab dan akibat gangguan citra tubuh

c. Diskusikan persepsi, perasaan, dan harapan klien terhadap citra tubuhnya

d. Menjelaskan perubahan-perubahan fisik yang terjadi pada ibu hamil

e. Motivasi klien untuk merawat dan meningkatkan citra tubuh seperti : menggunakan make up dan skincare untuk wajah yang berjerawat.

f. Motivasi klien untuk melakukan latihan meningkatkan citra tubuh sesuai jadwal dan beri pujian. 


\section{BAB 3}

TINJAUAN KASUS

\subsection{PENGKAJIAN KEPERAWATAN}

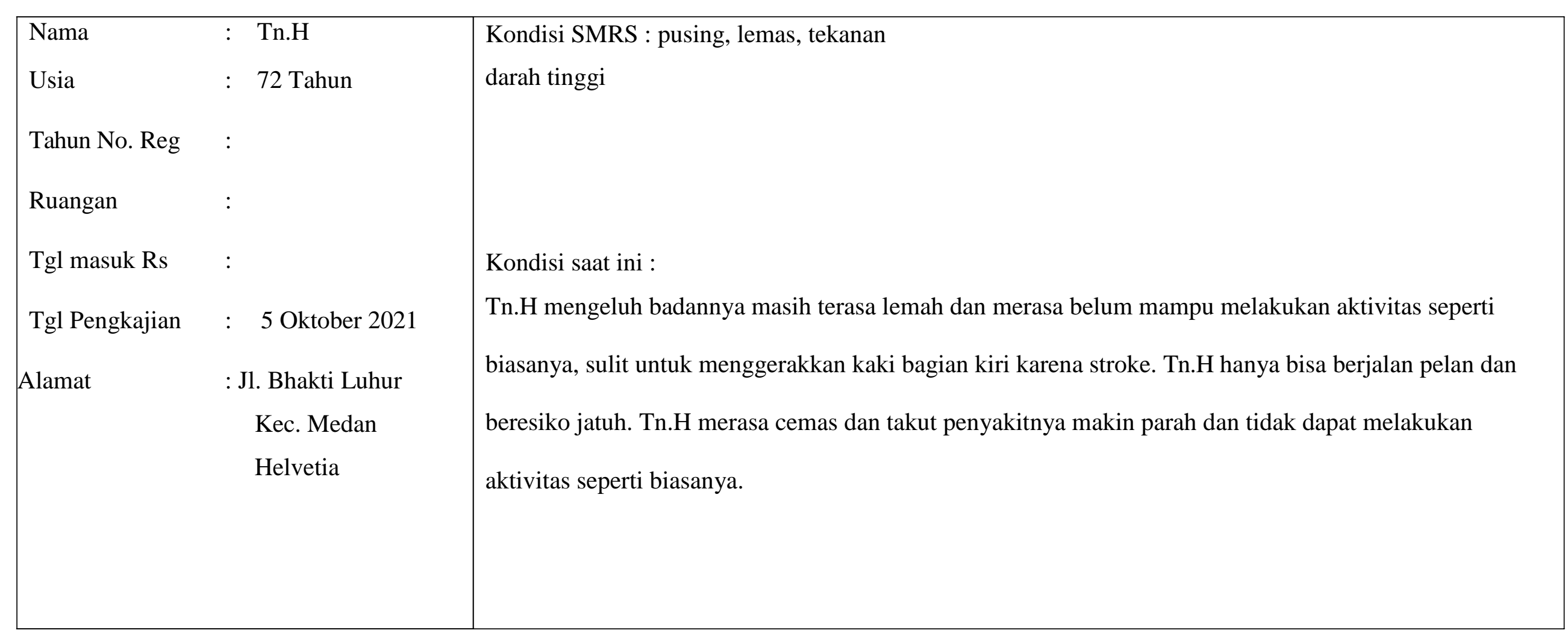




\subsubsection{FAKTOR PREDISPOSISI DAN FAKTOR PRESIPITASI}

\begin{tabular}{|c|c|c|c|c|}
\hline \multirow{2}{*}{$\begin{array}{c}\text { FAKTOR } \\
\text { PREDISPOSISI }\end{array}$} & \multicolumn{3}{|c|}{ FAKTOR PRESIPITASI } & \multirow{2}{*}{ STRESSOR } \\
\hline & NATURE & ORIGIN & $\begin{array}{c}\text { NUMBER \& } \\
\text { TIMING }\end{array}$ & \\
\hline $\begin{array}{l}\text { BSHOHOGIS: } \\
\text { - Stroke } \\
\text { - Tn. H menderita penyakit Stroke sejak } 2 \text { tahun yang lalu } \\
\text { - Tn. H coffee addict } \\
\text { - Tn. H tidak rutin check up ke Pelayanan kesehatan terkait } \\
\text { penyakit nya termasuk untuk mengukur tekanan darah }\end{array}$ & 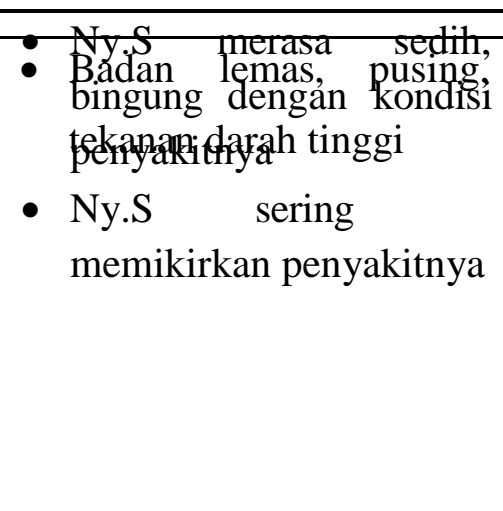 & Internal & $:^{2} 2$ minggu & $\begin{array}{l}\text { Sedih, ecmas, } \\
\text { kesal dan } \\
\text { briwgatikt stroke } \\
\text { dqniqantensi } \\
\text { kondisi } \\
\text { penyakit dan } \\
\text { pengobatan } \\
\text { serta } \\
\text { perawatannya }\end{array}$ \\
\hline - Tn. H memiliki riwayat Hypertensi & & & & \\
\hline
\end{tabular}


- Tn. H seorang Perempuan berumur 72 tahun

- Tn. H telah menikah dan memiliki 2 orang anak

- Tn. H merupakan Seoran Duda

- Tn. H merupakan orang jawa dan menurut Tn. H tidak ada kebiasaan yang bertentangan dengan kesehatan

- Tn. $\mathrm{H}$ beragama islam dan taat menjalankan ibadah

- Tn. H jarang check up penyakitnya

- Genogram

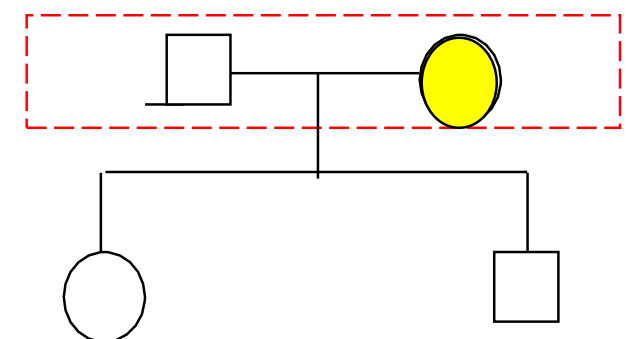

Ny.Stelah menikah dan memilki 2 orang anak. perempuah, anak pertama dan kedua laki-laku sudah merantau setelah menikahah.

- Tn. H tinggal bersama anak perempuannya

- Tn. H memiliki kepribadian terbuka, setiap ada masalah akan dibicarakan dengan anak perempuanya

- Tn. H merasa sedih dengan kondisi penyakitnya

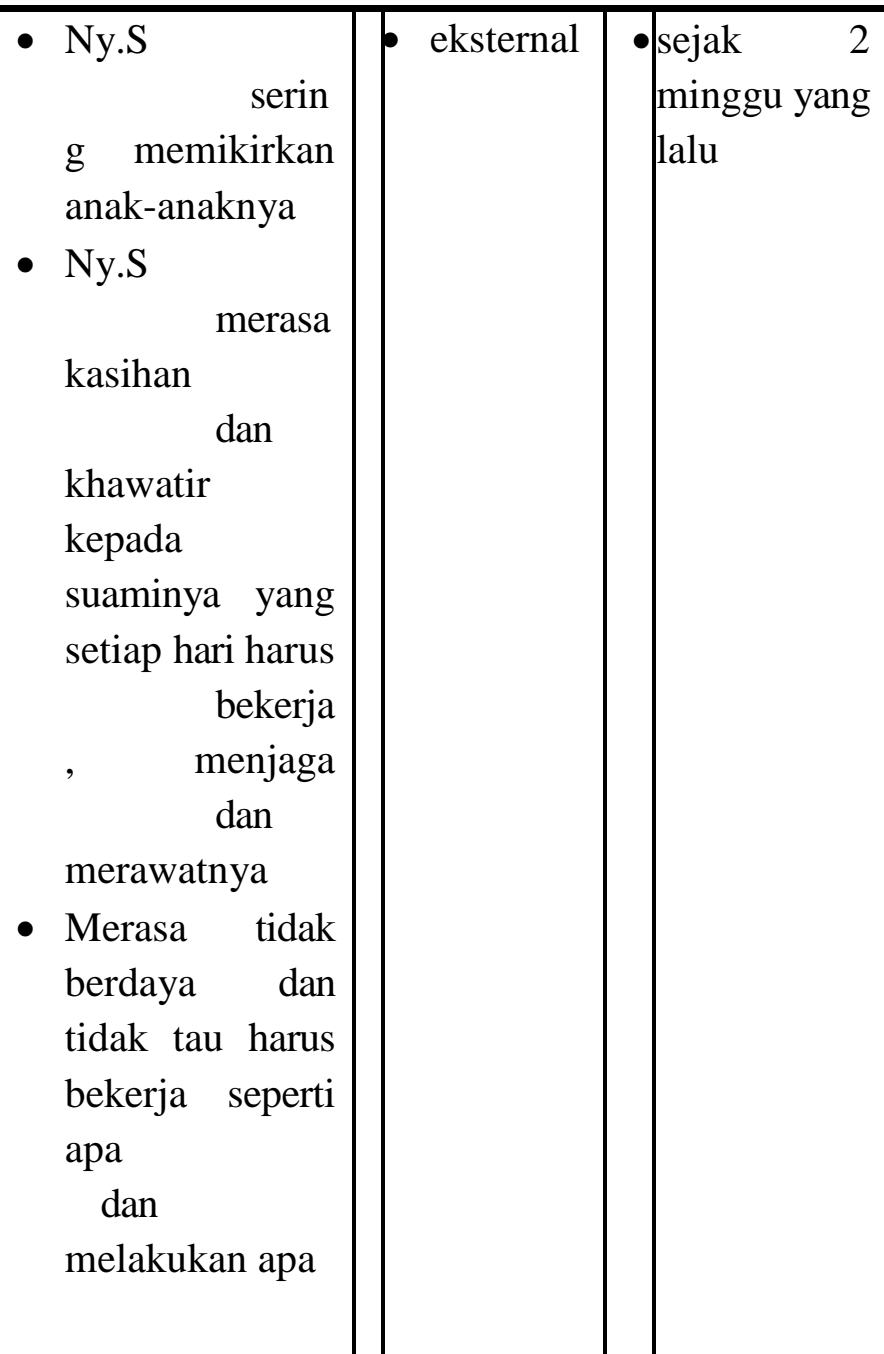

- sening memikirka n anakan kk mareka yg jauh merantau

- merasa kapihan kepada suami yang hatus menjaga dah merawat Ny.S setiap hati

- merasa bosan da tidak nyaman dehgan kondisi 
3.1.2 PENILAIAN (RESPON)TERHADAP STRESSOR

\begin{tabular}{|c|c|c|c|c|c|c|}
\hline STRESSOR & KOGNITIF & AFEKTIF & FISIOLOGIS & PERILAKU & SOSIAL & $\begin{array}{l}\text { DIAGNOSA } \\
\text { KEPERAWATAN }\end{array}$ \\
\hline $\begin{array}{l}\text { BIOLOGIS } \\
\text { - }(\text { Stroke) }\end{array}$ & $\begin{array}{l}\text { - Menurut Tn. H } \\
\text { penyakit } \\
\text { stroke } \\
\text { diakibatkan } \\
\text { karena } \\
\text { pengkonsumsi } \\
\text { kopi (coffee } \\
\text { addict) } \\
\text { - Menganggap } \\
\text { penyakit } \\
\text { yang diderita } \\
\text { serius } \\
\text { - Tidak tahu apa } \\
\text { yang harus } \\
\text { dilakukan } \\
\text { untuk } \\
\text { penyakitnya }\end{array}$ & $\begin{array}{l}\text { - Tn. H merasa } \\
\text { sedih dan } \\
\text { bingung } \\
\text { dengan } \\
\text { kondisi } \\
\text { penyakitnya }\end{array}$ & $\begin{array}{l}\text { - } \text { Pusing } \\
\text { - Sulit tidur } \\
\text { - } \text { Tidak nafsu } \\
\text { makan } \\
\text { - Ny.Stampak } \\
\text { lemas } \\
\text { - Pemeriksaan } \\
\text { TTV } \\
\text { TD: } 150 / 90 \\
\text { mmhg } \\
\mathrm{N}: 88 \times / \text { menit } \\
\text { P : } 22 \times / \text { menit } \\
\text { S: } 37{ }^{0} \mathrm{C}\end{array}$ & $\begin{array}{l}\text { - Tn. H } \\
\text { jarang } \\
\text { kontrol ke } \\
\text { rumah sakit } \\
\text { - Ekspresi } \\
\text { muka lesu } \\
\text { - Tn. H } \\
\text { tampak } \\
\text { lemas dan } \\
\text { berbaring } \\
\text { - Tn. H sering } \\
\text { berlatih untuk } \\
\text { menggerakka } \\
\text { n anggota } \\
\text { gerak }\end{array}$ & 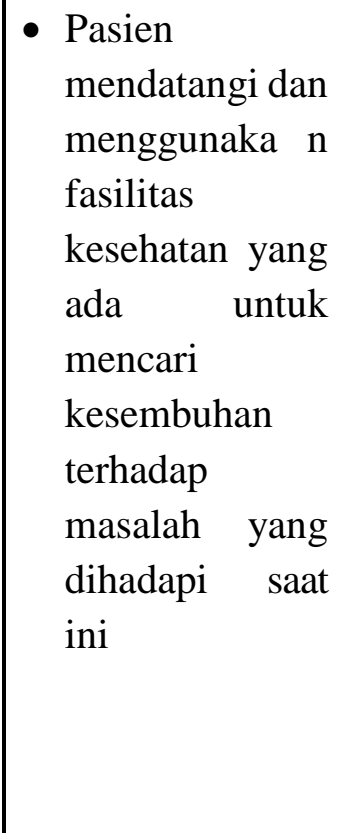 & - Ansietas \\
\hline $\begin{array}{l}\text { PSIKOLOGIS } \\
\text { - sedih, cemas, } \\
\text { kesal dan } \\
\text { Bingung } \\
\text { dengan kondisi } \\
\text { penyakit dan } \\
\text { pengobata } \\
\text { n serta }\end{array}$ & $\begin{array}{l}\text { - Tn. H tahu } \\
\text { bahwa } \\
\text { badannya } \\
\text { menjadi } \\
\text { lemah dan } \\
\text { kepalanya } \\
\text { pusing } \\
\text { merupakan } \\
\text { dampak dari } \\
\text { penyakit yang }\end{array}$ & $\begin{array}{l}\text { - Merasa kesal } \\
\text { dengan } \\
\text { penyakitnya } \\
\text { yang tidak } \\
\text { sembuh- } \\
\text { sembuh }\end{array}$ & $\begin{array}{l}\text { - } \text { Pusing } \\
\text { - } \text { Mual } \\
\text { - Sulit tidur dan } \\
\text { sering } \\
\text { terbangun } \\
\text { apabila tidur } \\
\text { - Bahu terasa } \\
\text { tegang } \\
\text { - Tidak nafsu }\end{array}$ & \begin{tabular}{|l} 
- Tampak \\
cemas dan \\
tidak \\
tenang \\
- Kadang Tn. \\
H tampak \\
murung \\
- Tn. H \\
tampak
\end{tabular} & \begin{tabular}{|l} 
- \\
Hubungan \\
Ny.Sdengan \\
suami baik \\
- Tn. H kurang \\
bersosialisasi \\
dengan \\
keluarga \\
Tn. H tetap \\
mengikuti \\
program
\end{tabular} & - Ansietas \\
\hline
\end{tabular}




\begin{tabular}{|c|c|c|c|c|c|c|}
\hline perawatannya & $\begin{array}{l}\text { diderita } \\
\text { - Tn. H } \\
\text { mengaku } \\
\text { bosan di } \\
\text { rumah sakit } \\
\text { Tn. H tidak } \\
\text { tahu } \\
\text { pengobatan } \\
\text { seperti apa lagi } \\
\text { yang dapat } \\
\text { dilakukan } \\
\text { untuk } \\
\text { mengobati } \\
\text { penyakitnya }\end{array}$ & & $\begin{array}{l}\text { makan } \\
\text { - Tn. H tampak } \\
\text { lemas } \\
\text { - Wajah Tn. H } \\
\text { tampak lemas } \\
\text { - Wajah Tn. H } \\
\text { tampak pucat } \\
\text { - Pemeriksaan } \\
\text { TTV } \\
\text { TD: } 150 / 90 \\
\text { mmhg } \\
\mathrm{N}: 88 \times / \text { menit } \\
\text { P: } 20 \times / \text { menit } \\
\text { S: } 36^{0} \mathrm{C}\end{array}$ & $\begin{array}{ll}\text { gelisah } & \\
\text { - } & \text { Tn. } \quad H \\
\text { tampak } & \\
\text { pasif dalam } \\
\text { menerima } & \\
\text { perawatan } & \\
\text { Tn. } & \mathrm{H} \\
\text { menunduk saat } & \text { bercerita }\end{array}$ & $\begin{array}{l}\text { pengobatan } \\
\text { yang } \\
\text { diberikan } \\
\text { kepadanya } \\
\text { akan tetapi } \\
\text { sikap Tn. H } \\
\text { pasif dalam } \\
\text { menerima } \\
\text { perawatan }\end{array}$ & - Ketidakberdayaan \\
\hline $\begin{array}{l}\text { SOSIAL } \\
\text { BUDAYA } \\
\text { • sering } \\
\text { Memikirkan } \\
\text { anak-anak } \\
\text { yang masih } \\
\text { Yang jauh dari } \\
\text { rumah merasa } \\
\text { kasihan kepada } \\
\text { suami yang } \\
\text { harus menjaga } \\
\text { dan } \\
\text { merawatnya } \\
\text { setiap hari. }\end{array}$ & $\begin{array}{l}\text { - Tn. H merasa } \\
\text { tidak berdaya } \\
\text { dengan } \\
\text { keadaannya } \\
\text { sejarang yang } \\
\text { tidak bisa } \\
\text { bekerja } \\
\text { bingung } \\
\text { memikirkan } \\
\text { anak-anak yang } \\
\text { jauh merantau } \\
\text { menurut klien, } \\
\text { dukungan } \\
\text { keluarga nomor } \\
\text { satu } \\
\text { - Tn. H berfikir } \\
\text { ia selalu } \\
\text { merepotkan } \\
\text { - suaminya bila }\end{array}$ & $\begin{array}{l}\text { - Merasa } \\
\text { khawatir dan } \\
\text { sedih kepada } \\
\text { suami yang } \\
\text { merawatnya } \\
\text { setiap hari } \\
\text { - Merasa } \\
\text { bersalah } \\
\text { karena } \\
\text { merasa } \\
\text { merepotkan } \\
\text { suami } \\
\text { - Merasa } \\
\text { bosan } \\
\text { dengan } \\
\text { keadaan } \\
\text { sekarang }\end{array}$ & $\begin{array}{l}\text { - Pusing } \\
\text { - Mual } \\
\text { - Mulut tampak } \\
\text { - kering } \\
\text { - Sulit tidur } \\
\text { - Bahu terasa } \\
\text { tegang } \\
\text { - Konstipasi } \\
\text { - Tidak nafsu } \\
\text { - } \text { makan } \\
\text { - lemas tampak } \\
\text { - Wajah Tn. H } \\
\text { tampak pucat } \\
\text { Pemeriksaan }\end{array}$ & $\begin{array}{ll}\text { - } & \text { Kontak mata } \\
\text { ada tapi tidak } \\
\text { bertahan } \\
\text { lama } \\
\text { - Volume } \\
\text { suara } \\
\text { mengecil } \\
\text { - Tn. } \\
\text { tampak } \\
\text { gelisah }\end{array}$ & $\begin{array}{l}\text { - Hubungan } \\
\text { Tn. H dengan } \\
\text { suami baik } \\
\text { - Hubungan } \\
\text { Tn. H dengan } \\
\text { petugas } \\
\text { kesehatan } \\
\text { baik } \\
\text { - Tn. H tetap } \\
\text { mengikuti } \\
\text { program } \\
\text { pengobatan }\end{array}$ & $\begin{array}{ll}\text { - Ansietas } \\
\text { ketidakberdayaan }\end{array}$ \\
\hline
\end{tabular}




$\left|\begin{array}{l|l|l|}\text { terlalu lama } \\ \text { dalam keadaan } \\ \text { seperti ini } \\ \text { merasa } \\ \text { Kasihan } \\ \text { kepada suami } \\ \text { yang harus } \\ \text { menjaga dan } \\ \text { merawat } \\ \text { klien. }\end{array}\right| \quad|\quad| \quad|\quad| \quad|\quad|$


3.1.3 SUMBER KOPING

\begin{tabular}{|c|c|c|c|c|c|}
\hline $\begin{array}{l}\text { DIAGNOSA } \\
\text { KEPERAWATAN }\end{array}$ & PERSONAL ABILITY & SOSIAL SUPPORT & $\begin{array}{l}\text { MATERIAL } \\
\text { ASSETS }\end{array}$ & $\begin{array}{l}\text { POSITIE } \\
\text { BELIEFS }\end{array}$ & TERAPI \\
\hline Ketidakberdayaan & $\begin{array}{l}\text { - Tn. H mampu } \\
\text { mengenal dan } \\
\text { menilai penyebab } \\
\text { ketidakberdayaan } \\
\text { - Tn. H mengatakan } \\
\text { bila cemasnya } \\
\text { memuncak maka ia } \\
\text { akan mengambil air } \\
\text { wudhu dan sholat } \\
\text { - Komunikasi Tn. H } \\
\text { dengan keluarganya } \\
\text { baik dan terjaga }\end{array}$ & $\begin{array}{l}\text { - } \text { Tn. } \\
\text { mendapat } \\
\text { dukungan dari } \\
\text { keluarga untuk } \\
\text { kesembuhanny } \\
\text { a terutama dari } \\
\text { suaminya } \\
\text { - Suami dan adik } \\
\text { Tn. H bergantian } \\
\text { merawat klien }\end{array}$ & $\begin{array}{l}\text { - Sosial ekonomi Tn. } \\
\text { H menengah } \\
\text { - Tn. H tinggal di } \\
\text { rumah sendiri, } \\
\text { rumah permanen } \\
\text { - Sarana dan } \\
\text { - prasarana tersedia } \\
\text { - Biaya } \\
\text { pengobatan } \\
\text { ditanggung oleh } \\
\text { asuransi kesehatan }\end{array}$ & $\begin{array}{l}\text { - Tn. H percaya } \\
\text { bahwa petugas } \\
\text { kesehatan akan } \\
\text { membantunya } \\
\text { - Tn. H berharap } \\
\text { cepat sembuh } \\
\text { agar tidak } \\
\text { merepotkan } \\
\text { suaminya }\end{array}$ & $\begin{array}{l}\text { - Sp1: } \\
\text { mengidenti } \\
\text { fikasi } \\
\text { penyakit } \\
\text { Dan } \\
\text { menggali } \\
\text { aspek } \\
\text { positif } \\
\text { Sp2 : } \\
\text { memberik } \\
\text { an penkes }\end{array}$ \\
\hline
\end{tabular}




\begin{tabular}{|c|c|c|c|c|c|}
\hline ANSIETAS & $\begin{array}{l}\text { Tn. H mampu } \\
\text { mengungkapkan } \\
\text { perasaan cemas } \\
\text { Tn. H mengatakan } \\
\text { bila cemasnya } \\
\text { memuncak maka ia } \\
\text { akan mengambil air } \\
\text { wudhu dan sholat }\end{array}$ & $\begin{array}{l}\text { - } \text { Tn. H mendapatkan } \\
\text { dukungan dari } \\
\text { keluarga tentang } \\
\text { kondisinya } \\
\text { - Tn. H dan keluarga } \\
\text { belum mendapat } \\
\text { pendidikan kesehatan } \\
\text { cara merawat klien }\end{array}$ & $\begin{array}{l}\text { - Jarak rumah Tn. H } \\
\text { dengan tempat } \\
\text { pelayanan } \\
\text { kesehatan lebih } \\
\text { kurang } 500 \text { meter }\end{array}$ & $\begin{array}{l}\text { - Tn. H selalu } \\
\text { berdoa } \\
\text { untuk } \\
\text { kesembuhan } \\
\text { penyakitnya } \\
\text { - Tn. H yakin, } \\
\text { bila ia } \\
\text { mengikuti }\end{array}$ & \begin{tabular}{|ll} 
Terapi spesialis: \\
- & Relaksasi \\
& progresif \\
- & Psikoedukasi \\
& keluarga \\
- & Behavior \\
& therapy \\
- & Psikoedukasi \\
& keluarga
\end{tabular} \\
\hline $\begin{array}{l}\text { Penampilan } \\
\text { peran tidak } \\
\text { efektif }\end{array}$ & $\begin{array}{l} \\
\square \text { Tn. H dapat } \\
\text { menyebutkan } \\
\text { penyebab } \\
\text { penampilan peran } \\
\text { tidak efektif } \\
\text { Tn. H menganggap } \\
\text { suami tidak mampu } \\
\text { sebagai pengganti } \\
\text { akibat kondisi yang } \\
\text { berubah }\end{array}$ & yang sakit & $\begin{array}{l}\text { - Sosial ekonomi } \\
\text { Tn. H menengah } \\
\text { - Tn. H tinggal di } \\
\text { rumah sendiri, } \\
\text { rumah permanen }\end{array}$ & $\begin{array}{l}\text { petunjuk dan } \\
\text { saran dari } \\
\text { petugas } \\
\text { kesehatan } \\
\text { maka ia akan } \\
\text { cepat sembuh } \\
\text { Tn. H yakin } \\
\text { suami dan } \\
\text { keluarga } \\
\text { mendukung } \\
\text { supaya lekas } \\
\text { sembuh } \\
\text { - Tn. H percaya } \\
\text { bahwa petugas } \\
\text { kesehatan akan } \\
\text { membantunya } \\
\text { Tn. } \mathrm{H} \\
\text { berharap } \\
\text { cepat sembuh } \\
\text { agar tidak } \\
\text { merepotkan } \\
\text { suaminya }\end{array}$ & \\
\hline
\end{tabular}




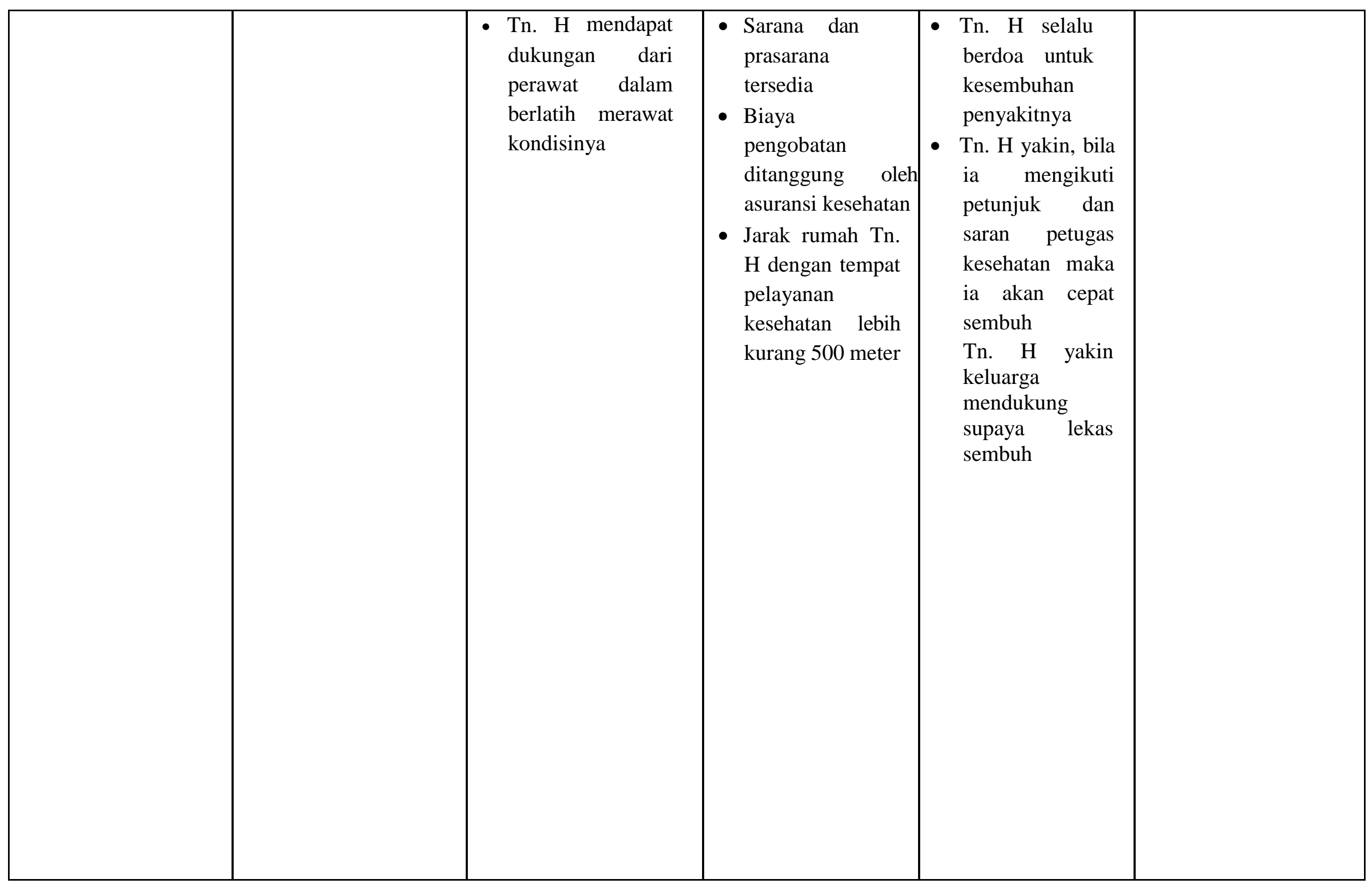




\begin{tabular}{|c|c|c|c|c|c|}
\hline $\begin{array}{l}\text { Kurang } \\
\text { pengetahuan }\end{array}$ & $\begin{array}{l}\text { - Tn. H mampu } \\
\text { mengenal dan } \\
\text { menilai Komplikasi } \\
\text { dari penyakitnya } \\
\text { - Tn. H mampu } \\
\text { melatih cara hidup } \\
\text { sehat }\end{array}$ & $\begin{array}{l}\text { - } \text { Tn. H mendapat } \\
\text { dukungan dari } \\
\text { keluarga untuk } \\
\text { kesembuhannya } \\
\text { terutama dari } \\
\text { suaminya } \\
\text { - Suami dan keluarga } \\
\text { Tn. H bergantian } \\
\text { menjaga dan } \\
\text { mengunjungi klien } \\
\text { - Tetangga Tn. H dan } \\
\text { teman di tempat } \\
\text { kerja juga banyak } \\
\text { yang mengunjungi } \\
\text { klien }\end{array}$ & $\begin{array}{l}\text { - Sosial ekonomi } \\
\text { Tn. H menengah } \\
\text { - Tn. H tinggal di } \\
\text { rumah sendiri, } \\
\text { rumah } \\
\text { permanen } \\
\text { - Sarana dan } \\
\text { prasarana } \\
\text { tersedia } \\
\text { - Biaya } \\
\text { pengobatan } \\
\text { ditanggung oleh } \\
\text { asuransi kesehatan } \\
\text { - Jarak rumah Tn. H } \\
\text { dengan tempat } \\
\text { pelayanan } \\
\text { kesehatan (RSMM) } \\
\text { lebih kurang } 500 \\
\text { meter }\end{array}$ & $\begin{array}{l}\text { - Tn. H percaya } \\
\text { bahwa petugas } \\
\text { kesehatan akan } \\
\text { membantunya } \\
\text { - Tn. H berharap } \\
\text { cepat sembuh } \\
\text { agar tidak } \\
\text { merepotkan } \\
\text { suaminya } \\
\text { Tn. H selalu } \\
\text { berdoa untuk } \\
\text { kesembuhan } \\
\text { penyakitnya } \\
\text { Tn. H yakin, } \\
\text { bila ia } \\
\text { mengikuti } \\
\text { petunjuk dan } \\
\text { saran dari } \\
\text { petugas } \\
\text { kesehatan maka } \\
\text { ia akan cepat } \\
\text { sembuh } \\
\text { Tn. H yakin } \\
\text { keluarga } \\
\text { mendukung } \\
\text { supaya lekas } \\
\text { sembuh }\end{array}$ & $\begin{array}{l}\text { Terapi generalis: } \\
\text { - SP 1-2 kurang } \\
\text { pengetahuan } \\
\text { Terapi spesialis: } \\
\text { - Terapi suportif, } \\
\text { FPE }\end{array}$ \\
\hline
\end{tabular}




\subsubsection{MEKANISME KOPING}

\begin{tabular}{|c|c|}
\hline $\begin{array}{c}\text { HAL YANG } \\
\text { DILAKUKAN }\end{array}$ & ANALISA \\
\hline $\begin{array}{l}\text { - Tn. H mengatakan bila ada masalah, maka ia akan membicarakan } \\
\text { - Bengan anaknya dan keluarga untuk mencari jalan keluarnya } \\
\text { - Tn. H taat menjalankan ibadah sesuai dengan keyakinannya } \\
\text { - Tn. H selalu berdoa kepada Allah SWT untuk kesembuhannya }\end{array}$ & $\begin{array}{l}\text { - Konstruktif: } \\
\checkmark \text { Tn. H mengatakan bila ada masalah, maka ia akan membicarakan } \\
\text { dengan suami dan keluarga untuk mencari jalan keluarnya } \\
\checkmark \text { Bila sakit Tn. H berobat ke pelayanan kesehatan } \\
\checkmark \text { Tn. H taat menjalankan ibadah sesuai dengan } \\
\text { keyakinannya } \\
\checkmark \text { Tn. H selalu berdoa kepada Allah SWT untuk } \\
\text { kesembuhannya. } \\
\text { - Destruktif : - }\end{array}$ \\
\hline
\end{tabular}




\subsubsection{STATUS MENTAL}

\begin{tabular}{|c|c|}
\hline 1. Penampilan & Bersih, rapi, tidak tercium bau, Ny.Stampak lemas \\
\hline 2. Pembicaraan & Lancar bicara \\
\hline 3. Aktivitas motoric & Tubuh bagin kaki kiri sulit digerakkan \\
\hline 4. Interaksi selama wawancara & Cukup kooperatif, meskipun afasia \\
\hline 5. Alam perasaan & Sedih, merasa cemas dan bingung mengenai kondisi penyakit, suami dan anak-anaknya \\
\hline 6. Afek & Datar \\
\hline 7. Persepsi & Tn. H mengalami gangguan dalam proses sensori-persepsi \\
\hline 8. Isi piker & Mengalami masalah karena sebagian memori terlupakan \\
\hline 9. Proses piker & masalah karena sebagian memori terlupakan \\
\hline 10. Tingkat kesadaran & Tn. H dapat menyebutkan kembali nama anak-anaknya \\
\hline 11. Daya ingat & Tn. H tidak dapat mengingat beberapa kejadian dalam hidupnya \\
\hline 12. Kemampuan berhitung & Kemampuan berhitung cukup baik \\
\hline 13. Penilaian & Tn. H belum mampu menyebutkan bagaimana caranya agar Tn. H lekas sembuh \\
\hline 14. Daya tilik diri & $\begin{array}{l}\text { Tn. H menyadari bahwa saat ini ia sedang sakit, Tn. H hanya bisa berdoa supaya lekas sembuh agar tidak } \\
\text { terus merepotkan anak-anaknya. Tn. H menyadari ia memiliki anak-anak dan keluarga yang menyayanginya } \\
\text { dan mendukung kesembuhannya }\end{array}$ \\
\hline
\end{tabular}

Kesimpulan : Mental Status Examination (MSE) tidak ada masalah gangguan jiwa, gangguan Tn. H lebih kepada Gangguan Mental Emosional (GME/Psikososial) 


\begin{tabular}{|c|c|}
\hline IMPLEMENTASI KEPERAWATAN & EVALUASI (SOAP) \\
\hline $\begin{array}{l}\text { Tanggal : } 05 \text { oktober } 2021 \\
\text { Jam : } 14.00 \text { wib } \\
\text { 1. Memahami dan menenangkan keadaan klien } \\
\text { 2. Memberikan informasi tentang diagnosa, } \\
\text { progrosis, dan tindakan } \\
\text { 3. Mengkaji tindakan dan reaksi fisik tingkat } \\
\text { ansiatas (kecemasan) } \\
\text { 4. Memahami klien untuk mendukung keamanan } \\
\text { dan rasa takut } \\
\text { 5. Mengajarkan klien teknik relaksi tarik napas } \\
\text { dalam } \\
\text { 6. Mendukung keterlibatan keluarga dengan cara } \\
\text { yang tepat } \\
\text { Tanggal : 08 Oktober 2021 } \\
\text { Jam: } 10.00 \text { wib } \\
\text { 1. Latihan cara mengatasi kecemasan: dengan } \\
\text { bercakap-cakap positif } \\
\text { 2. Latihaan cara mengatasi kecemasan dengan } \\
\text { hipnotis } 5 \text { jari } \\
\text { 3. Bantu klien melakukan latihan sesuai dengan } \\
\text { jadwal kegiatan }\end{array}$ & $\begin{array}{l}\mathrm{S}: \text { Klien mengatakan : kecemasannya berkurng setelah } \\
\text { menggungkapkan perasaanya, pasien meranas tenang, dan } \\
\text { mampu mengidentifikasi situasi yang mencetuskan } \\
\text { kecemasannya } \\
\mathrm{O} \text { : klien tanpak tenang setelah menggungkapkan perasaan } \\
\text { kecemasannya dan selalu melakukan teknik relaksasi tarik } \\
\text { napas dalam untuk mengontrol kecemasannya } \\
\text { A : Kecemasan pasien berkurang setelah melakukan teknik } \\
\text { relaksasi tarik napas dalam } \\
\mathrm{P}: \text { Intervensi yanng diberikan terus dilakukan klien yaitu teknik } \\
\text { relaksasi tarik napas dalam. }\end{array}$ \\
\hline
\end{tabular}




\section{BAB 4}

\section{PEMBAHASAN}

Setelah penulis melaksanakan asuhan keperawatan kepada Tn. H dengan Kecemasan di jalan bakti luhur maka penulis pada BAB ini akan membahasan kesenjangan antara teoritis dengan tinjauan kasus. Pembahasan dimulai melalui tahapan proses keperawatan yaitu pengkajian, diagnosa keperawatan, perencanaan, pelaksanaan dan evaluasi.

\subsection{Tahap Pengkajian}

Selama pengkajian dilakukan pengumpulan data dari beberapa sumber, yaitu dari pasien dan tetangga sekitar. Maka penulis melakukan pendekatan kepada pasien melalui komunikasi teraupetik yang lebih terbuka membantu klien untuk memecahkan perasaannya dan juga melakukan observasi kepada pasien. Adapun upaya tersebut yaitu :

a. Melakukan pendekatan dan membina hubungan saling percaya diri pada klien agar klien lebih terbuka dan lebih percaya dengan menggunakan perasaan.

b. Mengadakan pengkajian klien dengan wawancara Dalam pengkajian ini, penulis tidak menemukan kesenjangan karena ditemukan hal sama seperti: diteori: Ketidakberdayaan adalah persepsi atau tanggapan klien bahwa perilaku atau tindakan yang sudah dilakukannya tidak akan membawa hasil yang diharapkan atau tidak akan membawa perubahan hasil seperti yang diharapkan, sehingga klien sulit mengendalikan situasi yang terjadi atau mengendalikan situasi yang akan terjadi.

\subsection{Tahap Perencanaan}

Perencanaan dalam proses keperawatan lebih dikenal dengan rencana asuhan keperawatan yang merupakan tahap selanjutnya setelah pangkajian dan penentuan diagnosa keperawatan. Pada tahap perencanaan penulis hanya menyusun rencana tindakan keperawatan sesuai dengan pohon masalah keperawatan yaitu : Kecemasan. Pada tahap ini antara tinjauan teoritis dan tinjaun kasus tidak ada kesenjangan sehingga penulis dapat melaksanakan 
tindakan seoptimal mungkin dan didukung dengan seringnya bimbingan dengan pembimbing.

Secara teoritis digunakan cara strategi pertemuan sesuai dengan diagnosa keperawatan yang muncul saat pengkajian. Adapun upaya yang dilakukan penulis yaitu :

1. Klien mengungkapkan ketidak pastian tentang fluktuasi tingkat energi dan bersikap pasif.

2. Klien menunjukan sikap cemas, gelisan dan takut terhadap perburukan fisik yang terjadi dengan mengabaikan kepatuhan pasien terhadap program pengobatan

3. Klien mengalami ketergantungan pada orang lain yang dapat mengakibatkan ititabilitas, ketidak sukaan, marah dan rasa bersalah. Klien tidak melakukan praktik perawatan diri ketika ditantang. Klien tidak ikut memantau kemajuan pengobatan. Klien menunjukan ekspresi ketidak puasan terhadap ketidak mampuan melakukan aktivitas atau tugas sebelumnya. Klien menunjukan ekspresi keraguan tantang performa peran.

\subsection{Tahap Implementasi}

Pada tahap implementasi, penulis hanya mengatasi 1 masalah keperawatan yakni: diagnosa keperawatan Kecemasan merupakan respon emosional terhadap penilaian individu yang subjektif, dipengaruhi alam bawah sadar dan tidak diketahui secara khusus penyebabnya.

\subsection{Tahap Evaluasi}

Pada tinjauan teoritis evaluasi yang diharapkan adalah :

a. Membina hubungan saling percaya

b. Mengenali dan mengekspresikan emosinya

c. Memodifikasi pola kognitif yang negative 
d. Berpartisipasi dalam pengambilan keputusan yang berkenaan dengan perawatannya sendiri.

e. Termotivasi untuk aktif mencapai tujuan yang realistis. 


\section{BAB 5}

\section{PENUTUP}

\subsection{Kesimpulan}

Berdasarkan uraian pada pembahasan diatas, maka penulis dapat disimpulkan bahwa:

1. Pengkajian dilakukan secara langsung pada klien dan juga dengan menjadikan status klien sebagai sumber informasi yang dapat mendukung data-data pengkajian. Selama proses pengkajian, perawat mengunakan komunikasi terapeutik serta membina hubungan saling percaya antara perawat-klien. Pada kasus kecemasan: Stroke

2. Diagnosa keperawatan yang utama pada klien dengan Kecemasan: Stroke.

3. Perencanaan dan implementasi keperawatan disesuaikan dengan strategi pertemuan pada pasien.

4. Evaluasi keperawatan yang dilakukan menggunakan metode subyektif, obyektif, assessment dan planing.

\subsection{Saran}

1. Untuk institusi pendidikan

Diharapkan lebih meningkatkan pelayanan pendidikan yang lebih tinggi dan menghasilkan tenaga kesehatan yang profesional berwawasan global

2. Untuk keluarga

Diharapkan agar individu dan keluarga bisa mengerti tentang penyakit stroke, dan meningkatkan perilaku hidup sehat dengan tujuan meningkatkan kualitas hidup. 


\section{DAFTAR PUSTAKA}

1. Maria, I. (2020). Hubungan Pelaksanaan Range of Motion Dengan Risiko Dekubitus Pada Pasien Stroke. Jurnal Keperawatan Suaka Insan (Jksi), 5(1), 109-115.

2. Leniwita, H. L., Prabawati, D. P., \& Susilo, W. H. (2020). pengaruh latihan range of motion (rom) terhadap perubahan aktivitas fungsional pada pasien stroke rawat inap di RSU UKI Jakarta. Jurnal JKFT, 4(2), 72-77. http://dx.doi.org/10.31000/jkft.v4i2.2504

3. Amila, A., Sinaga, J., \& Sembiring, E. (2019). Pencegahan Stroke Berulang Melalui Pemberdayaan Keluarga Dan Modifikasi Gaya Hidup. Jurnal Abdimas, 22(2), 143-150.

4. Cory'ah, F. A. N., \& Wahyuni, I. G. A. P. S. (2019). Hubungan Sindrom Menopause Dengan Tingkat Kecemasan Ibu Menopause Diwilayah Kerja Puskesmas Ubung Kabupaten Lombok Tengah Tahun 2018. Jurnal Kebidanan Akademi Kebidanan Jember, 3(1), 8-16.

5. Zaini, M. (2019). Asuhan keperawatan Jiwa Masalah Psikososial Di Pelayanan Klinis dan Komunitas. Deepublish : Yogyakarta

6. Marbun, A., Pardede, J. A., \& Perkasa, S. I. (2019). Efektivitas Terapi Hipnotis Lima Jari terhadap Kecemasan Ibu Pre Partum di Klinik Chelsea Husada Tanjung Beringin Kabupaten Serdang Bedagai. Jurnal Keperawatan Priority, 2(2), 92-99. https://doi.org/10.34012/jukep.v2i2.568

7. Amila, A., \& Sembiring, E. (2020). Slow Stroke Back Massage (Ssbm) Dan Kecemasan Pasien Stroke. Jurnal Teknologi Kesehatan Dan Ilmu Sosial (TEKESNOS), 2(2), 01-10.

8. Pardede, J. A., Simanjuntak, G. V., \& Waruwu, J. F. A. P. (2020). Penurunan Tingkat Kecemasan Pasien HIV/AIDS melalui Terapi Hipnotis Lima Jari. Coping: Community of Publishing in Nursing, 8, 85-90.

9. Pardede, J., Simanjuntak, G. V., \& Manalu, N. (2020). Effectiveness of deep breath relaxation and lavender aromatherapy against preoperative patient anxiety. Diversity and Equality in Health and Care, 17(4), 168-173.

10. Pardede, J. A., Siregar, L. M., \& Hulu, E. P. (2020). Efektivitas Behaviour Therapy Terhadap Risiko Perilaku Kekerasan Pada Pasien Skizofrenia Di Rumah Sakit Jiwa Prof. Dr. Muhammad Ildrem Provsu Medan. Jurnal Mutiara Ners, 3(1), 8-14.

11. Pardede, J. A., \& Simangunsong, M. M. (2020). Family Support With The Level of Preschool Children Anxiety in the Intravenous Installation. Jurnal 
Keperawatan Jiwa (JKJ): Persatuan Perawat Nasional Indonesia, 8(3), 223-234.

12. Hayat, A. (2017). Kecemasan dan metode pengendaliannya. Khazanah: Jurnal Studi Islam Dan Humaniora, 12(1).

13. Febrianti, D., Hamid, A. Y. S., \& Wardani, I. Y. (2015). Gambaran Asuhan Keperawatan Pada Klien Hipertensi Dengan Ansietas Menggunakan Pendekatan Uncertainty in Illness Dan Comfort Theory. Jurnal Ilmu Kesehatan, 7(2), 113-118.

14. Pardede, J. A., Hulu, D. E. S. P., \& Sirait, A. (2021). Tingkat Kecemasan Menurun Setelah Diberikan Terapi Hipnotis Lima Jari pada Pasien Preoperatif. Jurnal Keperawatan, 13(1), 265-272.

15. Nurhalimah, Ns. (2016). Modul Keperawatan Jiwa. Jakarta.

16. Lestari, A. (2018). Pengaruh Terapi Psikoedukasi Keluarga Terhadap Pengetahuan Dan Tingkat Ansietas Keluarga Dalam Mera Wat Anggota Keluarga Yang Mengalami Tuberculosis Paru Di Kota Bandar Lampung. Jurnal Ilmiah Kesehatan, 1(1). https://doi.org/10.35952/jik.v1i1.105

17. Stuart. Gail. W, Keliat. Budi. Anna,\& Pasaribu. Jesika.(2016). Keperawatan keseha111tan jiwa: Indonesia : Elsever

18. Utami, T. W., Astuti, Y. S., \& Livana, P. H. (2017). Hubungan Kecemasan Dengan Depresi Pada Anak Sekolah Dasar. Jurnal Keperawatan, 9(1), 1-5.

19. Naja, G., Halasz, A., Thiboutot, S., Ampleman, G., \& Hawari, J. (2008). Degradation of hexahydro-1, 3, 5-trinitro-1, 3, 5-triazine (RDX) using zerovalent iron nanoparticles. Environmental science \& technology, 42(12), 4364-4370.

20. Wahyuningsih, A. S., Saputro, H., \& Kurniawan, P. (2021). Analisis Faktor Kecemasan terhadap Tingkat Kecemasan Pasien Pre Operasi Hernia di Rumah Sakit. Jurnal Keperawatan Jiwa (JKJ): Persatuan Perawat Nasional Indonesia, 9(3), 613-620.

21. Pardede, J. A., \& Tarigan, I. (2020). The Anxiety Level of Mother Presectio Caesar with Benson's Relaxation Therapy. JENDELA NURSING JOURNAL (JNJ), 4(1), 20-28. https://doi.org/10.31983/jnj.v4i1.5801

22. Pratiwi, S. R., Widianti, E., \& Solehati, T. (2017). Gambaran faktor-faktor yang berhubungan dengan kecemasan pasien kanker payudara dalam menjalani kemoterapi. Jurnal Pendidikan Keperawatan Indonesia, 3(2), 167-174. 
23. Sulastri, S., Trilianto, A. E., \& Ermaneti, Y. (2019). Pengaruh Komunikasi Terapeutik Perawat terhadap Tingkat Kecemasan pada Pasien Pre Operasi. Jurnal Keperawatan Profesional, 7(1). https://doi.org/10.33650/ikp.v7i1.503

24. Sumoked, A., Wowiling, F., \& Rompas, S. (2019). Hubungan Mekanisme Koping Dengan Kecemasan Pada Mahasiswa Semester Iii Program Studi Ilmu Keperawatan Fakultas Kedokteran Yang Akan Mengikuti Praktek Klinik Keperawatan. Jurnal Keperawatan, 7(1).

25. Pardede, J. A., Keliat, B. A., Damanik, R. K., \& Gulo, A. R. B. (2020). Optimalization of Coping Nurses to Overcoming Anxiety in the Pandemic of Covid-19 in Era New Normal. Jurnal Peduli Masyarakat, 2(3), 105-112. http://dx.doi.org/10.31000/jkft.v4i2.2504 